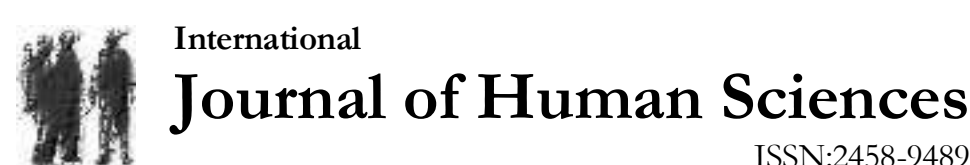

Volume 15 Issue 3 Year: 2018

\section{The predictors of school refusal: Depression, anxiety, cognitive distortion and attachment ${ }^{1}$}

\author{
Işıl Tekin ${ }^{2}$ \\ Seval Erden ${ }^{3}$ \\ Asiye Büşra Şirin Ayva $^{4}$ \\ Engin Büyüköksüz ${ }^{5}$
}

\begin{abstract}
School refusal is one of the main problems observed in almost all levels of education in Turkey. This problem is characterized by difficulties in going to school, staying at school for an entire day or not feeling well at school. School refusal is commonly associated with cognitive evaluations and emotional problems, and it may also be a source for various other problems. The purpose of this study is to do a research about the predictor power of depression, negative thoughts and attachment styles in school refusal through the sample of Turkish students. Furthermore, the school refusal behavior has also been analysed in terms of some demographical variables such as gender, perceived socio-economic level, and parents' educational level. The study group consisted of 340 secondary school students studying in Istanbul. School Refusal Assessment Scale-R, The Revised Child Anxiety and Depression Scale-Short Version, The Experiences in Close Relationships Middle Childhood, and Three Dimensions of Cognitive Scale were used as measurements. Results have indicated that school refusal is predicted by anxiety, depression and negative thoughts but is not predicted by attachment styles such as avoidance and anxiety attachment. The results have been presented and discussed in the light of the literature.
\end{abstract}

Keywords: School refusal; anxiety; depression; cognitive distortion; attachment.

\section{Introduction}

School refusal is a problem that many families, teachers and schools are familiar with. The term is used together with some concepts such as absenteeism, truancy, and school phobia. Absenteeism refers to "excusable or inexcusable absences from school" (Kearney, 2003). It means that it is a persistent or regular pattern of not attending school. It usually occurs within the knowledge and consent of a parent. Absent students are usually at home when they are expected to be at school. Truancy, on the other hand, generally refers to unexcused, illegal, surreptitious absenteeism. It can be stated that it is a form of non-anxiety-based absenteeism. Unlike absenteeism, students tend to hide truancy from their parents or they do it against the wishes of their parents. School phobia, generally refers a kind of absenteeism originated from fear

\footnotetext{
${ }^{1}$ Submitted in IX. European Conference on Social and Behavioral Sciences Congress, Paris, 3-6 February 2016.

2 Ph.D., Res. Ass., İstanbul Medeniyet University, Faculty of Educational Sciences, tekinisil1@gmail.com

3 Assoc. Prof. Dr., Marmara University, Atatürk Education Faculty, erdenseval@gmail.com

${ }_{4}$ Ph.D., busrasirin@hotmail.com

${ }^{5}$ Instructor, Okan University, Faculty of Education, engin.buyukoksuz@,okan.edu.tr
} 
Tekin, I., Erden, S., Şirin Ayva, A. B., \& Büyüköksüz, E. (2018). The predictors of school refusal: Depression, anxiety, cognitive distortion and attachment. Journal of Human Sciences, 15(3), 1519-1529. doi:10.14687/jhs.v15i3.5084

(Kearney, 2008b). This term is often used for early childhood students not for teenagers (Hanna, Fischer, \& Fluent, 2006). The confusion in concepts stems from the difficulty in identifying and monitoring the etiology of school refusal behaviour.

School refusal is an inclusive term that includes refusal of attending school and difficulties in school related activities (Kearney, 2008a). This term is used for all students who refuse to go to school or have difficulty in staying at school (Kearney and Bensaheb, 2006; Kearney \& Silverman, 1999) or feel difficulty in attending school activities (Kearney \& Silverman, 1999). School refusal behavior excludes school withdrawal or parent-motivated absenteeism (Kearney, 2008a). Researchers suggest four different functions for the school refusal behaviour. These functions are avoidance of school related distress, aversive social and appraising environments at school, seeking to draw attention of the significant others, and getting concrete rewards outside of the school (Kearney, 2008).

School refusal can be observed in all levels of education and resulted from various reasons. Generally, younger students (5-11 ages) refuse school with the purpose of drawing attention and avoiding from general negative effects, and they experience more separation anxiety (Kearney \& Roblek, 1997). Moreover, these students cannot manage to stay at school whole day; even when they can stay, they feel bad (Kearney, 2008a). For elder students (12-17 ages), school refusal behavior is displayed to gain solid tangible rewards out of the school or to avoid the environment of evaluation (Kearney, 2008a; Rubenstein \& Hastings, 1980). Adolescents having school refusal behavior frequently change their schools, feel school related fear and show behavioral problems (Kearney, 2001).

School refusal can be more frequently observed when students start a new class or school (1st grade of junior, senior or high school) compared to its rate observed among other grades and young adolescents (Kearney \& Bates, 2005). In China, while it was found out that 12, 15 and 18 years are peak ages of the school refusal (Wu, Liu, Huang, Mo, Lin 2013), in Turkey, age mean of the students applying psychiatry service with school refusal compliant was found to be $9,1( \pm 3,0)$. According to King and Bernstein (2001), peak ages of the students with school refusal are 6-7 and 10-12. These findings demonstrate that school refusal behavior can vary in different countries and different cultures.

School refusal behaviour refers to illegitimate, child-motivated absenteeism (Beidas, Crawley, Mychailyszn, Comer \& Kendall 2010; Kearney and Bensaheb, 2006) that does not result from health problems or parents (Kearney, 2008; Wimmer, 2008). From a psychodynamic perspective, school refusal can be an emotional problem arising from a dependent relationship especially with mother (Christogiorgos \& Giannakopolous, 2014). In the light of the results that associate school refusal and parents, it can be thought that there may be a relationship between school refusal and attachment styles. People with a form of insecure attachment are uncomfortable with getting closer to the others, and they have troubles to completely trust people; they are less adaptable to social life, more vulnerable to stress, and cannot control their feelings too much (Kesebir, Kavzoğlu, \& Üstündağ, 2011). According to Moss and St-Laurent (2001), children with secure attachment perform better than their insecure peers in lots of areas such as communication, cognitive engagement, and mastery motivation. Therefore, it is thought that insecure attachment style may lead to school refusal.

Anxiety is the other related variables to school refusal behaviours. Clinically, school refusal behaviour is evaluated as a symptom of conduct disorder and a kind of anxiety such as separation anxiety, social anxiety, general anxiety, and severe anxiety. Each of them may function as a significant variable in the emergence of school refusal behaviour. As a form of anxiety, separation anxiety is assumed to be an important factor creating school refusal. The studies (Bagnell, 2011; Bahal, Tahiroğlu, \& Avc1, 2009; Christogiorgos \& Giannakopoulos, 2014; Özcan, Kilıç, Aysev, 2006) have indicated that children experiencing school refusal also suffered from separation anxiety and anxiety disorders. When separation anxiety is fundamental to school refusal, it is necessary to focus on the mother-child relationship. Separation anxiety emerge when 
Tekin, I., Erden, S., Şirin Ayva, A. B., \& Büyüköksüz, E. (2018). The predictors of school refusal: Depression, anxiety, cognitive distortion and attachment. Journal of Human Sciences, 15(3), 1519-1529. doi:10.14687/jhs.v15i3.5084

a child is separated from the mother or the attachment figure or when $\mathrm{s} /$ he is expected to leave. The relationship is closely related to unresolved dependency relationships (Fremont, 2003). The studies (Bagnell, 2011; Christogiorgos \& Giannakopoulos, 2014) presented that mothers of children with school refusal prefer their children to be dependent on them. On the other hand, general anxiety also leads to school refusal behaviours. Children with generalized anxiety are constantly concerned about future events. They are worried about not being good enough in various fields such as school success and sporting activities. Family dynamics, dependent parental attitudes, and realistic fears may bring about anxiety, and the effect of anxiety also leads to school refusal behaviours.

Depression is another predictive variable of school refusal and it is accompanied by strong levels of anxiety. In many studies (King \& Bernstein, 1991; Fremont, 2004; Haight, Kearney, Hendron \& Schafer, 2011; Last \& Strauss, 1990), it was stressed that depression and worry could be observed among children who refuse school. Egger, Castello and Angold (2003) claimed that depression can be accompanied by strong levels of anxiety, and young people suffer from some symptoms such as using alcohol and drugs, school refusal, and truancy. In a similar study, Reid (2000) stated that school refusers have sleeping problems/difficulties, low selfesteem, a low academic self-concept, and a heightened sensitivity to school failures. They also indicated these are reasons both for emotional problems like depression and school refusal behaviours.

On the other hand, the thinking structure and cognitive errors that the child has developed about himself and the school can also be the reason for school refusal. From a cognitive perspective, emotional and behavioural problems stem from faulty or negative ways of thinking. The kind of thinking including irrational beliefs and automatic thoughts are dysfunctional, inappropriate, irrational, or illogical cognitions. These construct from the disruptive cognitions and called as "cognitive errors" (Beck, 1995; Beidas, Crawley, Mychailyszyn, Comer, \& Kendall, 2010). Kendall (1991) hypothesizes that cognitive deficits play a greater role in externalizing problems, while cognitive distortions play a greater role in internalizing problems. Similarly, Maric, Heyne, MacKinnon, Widenfelt, and Westenberg (2012), claimed that negative automatic thoughts related aversion, and negative overgeneralizing cognitive distortion predict school refusal behaviour. For this reason, cognitive-behavioural techniques are mostly used techniques when studying on school refusal to define and alter school related irrational thoughts, and to reintegrate them into a specific school setting (Heyne, King, Tonge, \& Cooper 2001; Kearney, 2008b).

School refusal may cause short and long term adverse outcomes (Kearney, 2001). Possible short-term problems would be deterioration of the family routine, accordingly intense family conflict and increase of the economic expenses. Also, school refusal may result in crime, less academic performance, alienation from peers and school, and discipline problems for the children. Furthermore, long term problems related the school refusal would be school dropout, tendency to juvenile delinquency, less psychological function, anxiety, depression, alcohol use problems, criminal behaviours, psychological problems requiring psychiatric support, vocational problems for children, and marriage problems for families (Barth, 1984; Iwata, Hazama, Nakagome, 2012; Kearney and Bensaheb, 2006; Kearney \& Hugelshofer, 2000; Kearney, 2001; Last \& Strauss, 1990; Sewell, 2008; Wimmer, 2008).

The aim of this study is to analyse the predictive power of attachment, anxiety, depression, and negative thoughts of the students for school refusal behaviour. Additionally, the school refusal behaviour is analysed in terms of some demographical variables such as gender, perceived economic level, and parents' educational level. 
Tekin, I., Erden, S., Şirin Ayva, A. B., \& Büyüköksüz, E. (2018). The predictors of school refusal: Depression, anxiety, cognitive distortion and attachment. Journal of Human Sciences, 15(3), 1519-1529. doi:10.14687/ihs.v15i3.5084

\section{Method and materials}

\subsection{Study Design}

This study is based on correlational study model which aims to reveal the relationship between school refusal and attachment, anxiety, depression, negative thoughts. In this kind of design, it is aimed both to define a previous or current event, person or object in its own conditions, and to determine the existence and degree of mutual exchange between two or more variables (Karasar, 2006).

\subsection{Sample}

The sample of this study consisted of 340 students attending 4 different secondary schools in Istanbul. The data was gathered from students studying at $5^{\text {th }}$ to $8^{\text {th }}$ grades in fall term, in 2015. 83 of the students are $5^{\text {th }}$ grade $(24,4), 69$ of them are $6^{\text {th }}$ grade $(20,3 \%), 129$ of them are $7^{\text {th }}$ grade $(37,9 \%)$ and 59 of them are $8^{\text {th }}$ grade $(17,4 \%)$. In terms of gender distribution, 195 of the participants are female $(57,4 \%)$ and 145 of them are male $(42,6 \%)$. The education levels of participants' mothers are as follows: $126(37,1 \%)$ of them graduated from primary school, 69 $(20,3 \%)$ of them graduated from secondary school, $89(26,2 \%)$ of them graduated from high school, and $56(16,5 \%)$ of them graduated from university. On the other hand, when fathers' educational levels are considered, $81(23,8 \%)$ of them graduated from primary school, $72(21,2 \%)$ of them graduated from secondary school, $108(31,8 \%)$ of them graduated from high school, and $79(23,2 \%)$ of them graduated from university. In terms of perceived socio-economic status, 110 $(32,4 \%)$ of them reported that they are in low socio-economic level, while $186(54,7 \%)$ of them are in middle class level, and 44 (12,9\%) of them are in high socio-economic level.

\subsection{Instruments}

School Refusal Assessment Scale-R, The Revised Child Anxiety and Depression ScaleShort Version, and Three Dimensions of Cognitive Scale were used as instruments. Moreover, Personal Information Form was also used to acquire demographic information.

\subsubsection{School Refusal Assessment Scale - R}

The inventory was developed by Kearney and Silverman (1993) to assess school refusal behavior. The scale was revised by Haight, Kearney, Hendron and Schafer (2011) and adapted into Turkish language by Seçer (2014). It consists of 19 items with a 7-point scale from "never" to "always. This scale has four subscales called avoidance of school related distress, aversive social and evaluative environments at school, seeking to gain attention from the significant others, and to gain tangible rewards outside of the school. All of them are explaining 52,69\% of total variance. Cronbach's alpha coefficient was .86 for total scale and respectively $.82, .84, .84$, .81 for factors. Spearman split half and test-retest reliability coefficients were found to be $.85(.82$, $.84, .84$ and .81 for factors) and $.86(.87, .88, .88$ and .85$)$ respectively (Seçer, 2014).

\subsubsection{The Revised Child Anxiety and Depression Scale-Short Version}

The scale was developed by Spence (1997) and revised by Chorpita, Yim, Moffitt, Umemoto, and Francis (2000); and shortened by Ebesutani, Reise, Chorpita, Ale, Regan Young and Higa-McMillan (2012). In the shortened version, there are 25 items of the scale. 15 items of them measure anxiety and the other 10 items measure depression. Turkish adaptation was carried out by Seçer and Şimşek (2015). Findings of confirmatory factor analysis indicated the followings: RMSEA: .071, RMR: 065, SRMR: .070, NFI: .97, CFI: .98. Factor loadings ranged between .32 and .75. Cronbach's alpha coefficient, Spearman split half reliability and test-retest reliability coefficients were found to be respectively .89, .85 and .91, (Seçer and Şimşek, 2015).

\subsubsection{The Experiences in Close Relationships-R - Middle Childhood}

This measurement tool was developed by Fraley, Waller, and Brennan (2000) in order to evaluate adults' attachment, and was adopted into 'Turkish language by Selçuk, Günaydın, Sümer and Uysal (2005). This scale was reviewed to make the scale measure overall attachment dynamics in middle childhood by Brenning, Soenens, Braet, and Bosmans (2011). This version of scale was adopted into Turkish by Kırımer, Akça and Sümer (2014). The Scale consists of 36 items, as being 18 items in each subscale; attachment anxiety and attachment avoidance. Participants rank 
Tekin, I., Erden, S., Şirin Ayva, A. B., \& Büyüköksüz, E. (2018). The predictors of school refusal: Depression, anxiety, cognitive distortion and attachment. Journal of Human Sciences, 15(3), 1519-1529. doi:10.14687/jhs.v15i3.5084

the scale on a 7-point rating scale. According to the results of principal components factor analysis, items explain 36.38 of total variance (attachment anxiety explains $18.66 \%$ and attachment avoidance explains $17.72 \%$ ). Cronbach's alpha coefficient was .90 for the avoidance subscale, and .78 for the anxiety subscale. The correlation between attachment anxiety and attachment avoidance was positively significant $(\mathrm{r}=.49, \mathrm{p}<.01)$ (Kırımer, Akça \& Sümer, 2014).

\subsubsection{Three Dimensions of Cognitive Scale}

This scale was developed by Bilgin (2004) to measure cognitive trio to self, experience and future. Consisting of 30 items, the scale has three factors on a 5-point rating scale. The results of factor analysis have indicated that three factors explain $53.98 \%$ of total variance. The reliability analysis results were as follows; internal consistency coefficient was .93; item-total correlation coefficients were .02 to .71 ; test-retest coefficient was .58; and split half coefficient was .80 .

\section{Results}

Standard deviations and means analysis were carried out as preliminary analyses. The results can be seen in Table 1.

Table 1. Standard deviations and means of the study variables

\begin{tabular}{lccccc}
\hline & N & Minimum & Maximum & Mean & Std. Deviation \\
\hline School refusal & 340 & 19.00 & 82.00 & 44.08 & 10.40 \\
Attachment avoidance & 340 & 18.00 & 126.00 & 43.98 & 20.49 \\
Attachment anxiety & 340 & 18.00 & 104.00 & 38.36 & 13.58 \\
Anxiety & 340 & 15.00 & 56.00 & 24.79 & 6.67 \\
Depression & 340 & 10.00 & 40.00 & 16.23 & 4.74 \\
Negative Thoughts & 340 & 30.00 & 134.00 & 43.96 & 16.11 \\
\hline
\end{tabular}

Minimum and maximum scores, means and standard deviations of the variables were presented in Table 1. Means were calculated as $44.08(\mathrm{SD}=10.40)$ for school refusal; as 43.98 $(\mathrm{SD}=20.49)$ for attachment avoidance; as $38.36(\mathrm{SD}=13.58)$ for attachment anxiety; as 38.36 $(\mathrm{SD}=13.58)$ for anxiety; as $16.23(\mathrm{SD}=4.74)$ for depression; and as $43.96(\mathrm{SD}=16.11)$ for negative thoughts.

After the preliminary analysis, correlations of the study variables were examined. The findings are presented in Table 2.

Table 2. Correlations among study variables

\begin{tabular}{lccccc}
\hline Groups & $\begin{array}{c}\text { Attachment } \\
\text { avoidance }\end{array}$ & $\begin{array}{c}\text { Attachment } \\
\text { anxiety }\end{array}$ & Anxiety & Depression & $\begin{array}{c}\text { Negative } \\
\text { thoughts }\end{array}$ \\
School refusal & $.13^{*}$ & $.32^{* *}$ & $.45^{* *}$ & $.43^{* *}$ & $.31^{* *}$ \\
Attachment & & $.39^{* *}$ & $.21^{* *}$ & $.32^{*}$ & $.32^{*}$ \\
Attachment & & $.46^{* *}$ & $.42^{* *}$ & $.39^{* *}$ \\
Anxiety & & & $.71^{* *}$ & $.36^{* *}$ \\
Depression & & & & $.40^{* *}$ \\
\hline
\end{tabular}
${ }_{\mathrm{p}}^{*}<.05,{ }^{* *} \mathrm{p}<.01$ 
Tekin, I., Erden, S., Şirin Ayva, A. B., \& Büyüköksüz, E. (2018). The predictors of school refusal: Depression, anxiety, cognitive distortion and attachment. Journal of Human Sciences, 15(3), 1519-1529. doi:10.14687/jhs.v15i3.5084

As can be seen in Table 2, according to the results of Pearson Moment Correlation, school refusal was significantly correlated with attachment avoidance $(\mathrm{r}=.13, \mathrm{p}<05)$, attachment anxiety $(\mathrm{r}=.32, \mathrm{p}<01)$, anxiety $(\mathrm{r}=.45, \mathrm{p}<01)$, depression $(\mathrm{r}=.43, \mathrm{p}<01)$, and negative thoughts $(\mathrm{r}=.31, \mathrm{p}<01)$. In terms of attachment styles, avoidance style was correlated with anxiety $(\mathrm{r}=.21$, $\mathrm{p}<01)$, depression $(\mathrm{r}=.32, \mathrm{p}<01)$, and negative thoughts $(\mathrm{r}=.32, \mathrm{p}<01)$; anxiety attachment style was also correlated with anxiety $(\mathrm{r}=.47, \mathrm{p}<01)$, depression $(\mathrm{r}=.42, \mathrm{p}<01)$, and negative thoughts $(\mathrm{r}=.39, \mathrm{p}<01)$. Moreover, a positive and significant relationship was found between anxiety and depression $(\mathrm{r}=.71)$, and negative thoughts $(\mathrm{r}=.36)$. Finally, depression and negative thoughts were also positively correlated (.40).

Multiple regression analysis was applied to define the predictive power of these variables on school refusal. Results are given in Table 3.

Table 3. Regression analysis predicting school refusal using measures of attachment, anxiety and depression and negative thoughts

\begin{tabular}{lcccccccc}
\hline Variables & $\mathbf{B}$ & $\mathbf{S E}_{\mathbf{B}}$ & $\boldsymbol{\beta}$ & $\mathbf{T}$ & $\mathbf{p}$ & $\mathbf{R}$ & $\mathrm{R}^{2}$ & $\mathbf{F}$ \\
\hline Constant & 23.00 & 2.14 & & 10.74 & .000 & & & \\
Attachment avoidance & -.03 & .03 & -.05 & -.99 & .32 & & & \\
Attachment anxiety & .09 & .05 & .11 & 1.83 & .07 & .50 & .25 & $22.09^{* * *}$ \\
Anxiety & .38 & .11 & .24 & $\mathbf{3 . 3 8 ^ { * * }}$ & .00 & & & \\
Depression & .40 & .16 & .18 & $\mathbf{2 . 5 3 *}$ & .01 & & & \\
Negative thoughts & .09 & .04 & .12 & $\mathbf{2 . 2 8 ^ { * }}$ & .02 & & & \\
\hline
\end{tabular}

As the results revealed, the predictive role of the independent variables was proven to be statistically significant $(\mathrm{F}=22.09, \mathrm{p}<.001)$. Collectively, attachment avoidance, attachment anxiety, anxiety, depression, and negative thoughts accounted for approximately $25 \%$ of the variance in school refusal. $\beta$ scores indicate that anxiety $(\beta=.24, \mathrm{p}<.01)$ had the strongest effect on school refusal. The second predictor that contributed to the model was depression $(\beta=.18, \mathrm{p}<.05)$. Finally, negative thoughts also predicted school refusal $(\beta=.12, p<.05)$. In other respects, school refusal was not predicted by attachment styles (avoidance and anxiety attachment $\beta=-.05, \mathrm{p}>.05$ and $\beta=.11, \mathrm{p}>.05$ respectively).

The effects of gender, perceived socio-economic level, and education level of parents on school refusal were also investigated and results are presented in Table 4, Table 5 and Table 6.

Table 4. The results of t-Test for School Refusal in terms of gender

\begin{tabular}{llllllllll}
\hline \multirow{2}{*}{ Score } & Groups & $N$ & $\boldsymbol{\mu}$ & $S D$ & & \multicolumn{3}{c}{ SE $\boldsymbol{\mu}$} & \multicolumn{2}{c}{ Test } \\
\cline { 6 - 10 } & & & & & & & $\boldsymbol{t}$ & $d f$ & $p$ \\
\hline \multirow{2}{*}{ School Refusal } & Female & 195 & 44.16 & 10.47 & .75 & & & \\
& Male & 145 & 43.96 & 10.35 & .86 & & & .86 \\
\hline
\end{tabular}

The results of independent sample group t-test indicated that there was no significant difference in school refusal between females and males. 
Tekin, I., Erden, S., Şirin Ayva, A. B., \& Büyüköksüz, E. (2018). The predictors of school refusal: Depression, anxiety, cognitive distortion and attachment. Journal of Human Sciences, 15(3), 1519-1529. doi:10.14687/jhs.v15i3.5084

Table 5. The results of ANOVA for School Refusal in terms of Perceived SocioEconomic Level

\begin{tabular}{lccccccccc}
\hline Group & $\mathbf{N}$ & $\boldsymbol{\mu}$ & SD & $\begin{array}{c}\text { Source of } \\
\text { Variance }\end{array}$ & $\begin{array}{c}\text { Sum of } \\
\text { Square }\end{array}$ & df & $\begin{array}{c}\text { Mean } \\
\text { Square }\end{array}$ & $F$ & $p$ \\
\hline Low & 110 & 46.07 & 11.14 & Between & 780.59 & 2 & 390.29 & & \\
Middle & 186 & 43.50 & 10.32 & Within & 35916.58 & 33 & 106.58 & 3.67 & 0.27 \\
High & 44 & 41.54 & 7.90 & Total & 36697.17 & 33 & & & \\
Total & 340 & 44.08 & 10.40 & & & & & & \\
\hline
\end{tabular}

ANOVA findings represented that students' school refusal scores statistically vary in accordance with their perceived socio-economic status $(\mathrm{F}=3.67, \mathrm{p}<.05)$. According to Scheffe post hoc test, this difference has taken place between low and high socio-economic levels. Students having low socio-economic status have higher school refusal scores. It means that they are more inclined to school refusal problems.

Table 6. The results of ANOVA for School Refusal in terms of Parent's Educational Level

\begin{tabular}{|c|c|c|c|c|c|c|c|c|c|}
\hline Group & $\mathbf{N}$ & $\mu$ & SD & $\begin{array}{l}\text { Source of } \\
\text { Variance }\end{array}$ & $\begin{array}{l}\text { Sum of } \\
\text { Square }\end{array}$ & df & $\begin{array}{l}\text { Mean } \\
\text { Square }\end{array}$ & $F$ & $p$ \\
\hline \multicolumn{10}{|c|}{ Mother's Educational Level } \\
\hline Primary Sch. & 126 & 43.59 & 10.44 & Between Groups & 81.99 & 3 & 27.33 & \multirow{4}{*}{.25} & \multirow{4}{*}{.86} \\
\hline Secondary Sch. & 69 & 43.98 & 11.25 & Within Groups & 36615.17 & 336 & 108.97 & & \\
\hline High Sch. & 89 & 44.66 & 10.38 & \multirow[t]{2}{*}{ Total } & & & & & \\
\hline University & 56 & 44.53 & 9.44 & & & & & & \\
\hline \multicolumn{10}{|c|}{ Father's Educational Level } \\
\hline Primary Sch. & 81 & 45.64 & 10.99 & Between Groups & 289.86 & 3 & 96.62 & \multirow{4}{*}{.90} & \multirow{4}{*}{.45} \\
\hline Secondary Sch. & 72 & 43.03 & 10.22 & Within Groups & 36407.31 & 336 & 108.36 & & \\
\hline High Sch. & 10 & 43.82 & 10.31 & Total & 36697.17 & 339 & & & \\
\hline University & 79 & 43.79 & 10.11 & & & & & & \\
\hline
\end{tabular}

As can be seen in Table 6, there is no significant difference in school refusal scores $(\mathrm{F}=.25, \mathrm{p}>.05, \mathrm{~F}=.90, \mathrm{p}>.05$, respectively) regarding educational level of mothers and fathers.

\section{Discussion and Conclusion}

The main aim of this study is to define the predictive power of attachment styles, anxiety, depression, and negative thoughts on school refusal. It has been found out that attachment styles, anxiety, depression, and negative thoughts are correlated with school refusal. Based on the correlations, the predictivity of the variables on school refusal was examined. The findings indicated that anxiety, depression, and negative thoughts are predictors for school refusal.

Parallel with our findings, in the previous studies (Bagnell, 2011; Bahalı, Tahiroğlu, \& Avc1, 2009; Christogiorgos \& Giannakopoulos, 2014; Özcan, Kılıç, Aysev, 2006) it was found that school refusal is related to separation anxiety and anxiety disorders. When the child is expected to leave from her/his mother or attachment figure, s/he start to experience anxiety. It 
Tekin, I., Erden, S., Şirin Ayva, A. B., \& Büyüköksüz, E. (2018). The predictors of school refusal: Depression, anxiety, cognitive distortion and attachment. Journal of Human Sciences, 15(3), 1519-1529. doi:10.14687/jhs.v15i3.5084

was accepted that emerging anxiety stem from unresolved dependency relationships between the child and the mother (Fremont, 2003). Moreover, general anxiety can be also seen as a reason. Because of anxiety, the child cannot take himself away from fear of failure, concern with future events. For these reasons, instead of forcing children to return to school, enriching and changing the parent-child relationship is the best way to deal with the problems.

In the current study, it has been obtained that depression is another predictive variable of school refusal. This finding is supported by the previous studies (Egger, Castello and Angold, 2003; Reid 2000). Depression among children and adolescents is closely associated with irritability and feeling upset. If feeling upset endures for long periods, children suffering from depression can suddenly lose their ability to take pleasure from everyday activities. In times the children can isolate themselves entirely from both friends and family. It results in a refusal of going school, and attention and concentration difficulties occurring because of depression (Egger et al., 2003). Moreover, the characteristics and attitudes of the parents are accepted as risk factors for school refusal. In many studies (Bahalı, 2008; Bahalı, Tahiroğlu, Avc1, and Seydaoğlu, 2011; Martin, Cabrol, Bouvard, Lepine, \& Mouren-Simeoni, 1999; Özcan, Kılıç, Aysev, 2006) it is pointed that the parents of children experiencing school refusal had higher anxiety and clear signs of depression. These are interactional factors that cause school refusal. In line with the literature, our study showed that the problems created by depression are also effective in school refusal.

Another predictive variable on school refusal was negative thoughts. Negative attributions related to self and school such as friends, teachers, school environment, social threat, personal failure, and over generalization may cause problems. The attributions that the child will be incompetent at school constitute negative thoughts about the self, and it results in school refusal. These cognitive distortions affect children both academically and emotionally (Maric et al., 2012). When the level of negative thoughts gets higher, children start feeling bad. Since negative thoughts prevent refusers from solving their problems effectively, the thoughts trigger to yield negative events, and inevitably, anxiety occurs (Dube \& Orpinas, 2009). Hence, this situation creates a vicious cycle.

When the predictive power of attachment styles was analysed, it was found out that attachment styles did not predict school refusal as a main variable. This finding is inconsistent with previous studies (Barth, 1984; Kearney and Hugelshofer, 2000; Last \& Strauss, 1990). In our study, although the correlations were considered among attachments styles and school refusal behaviours, attachment styles did not have predictive power on the main variable. This is an unexpected result because attachment is based on caregiver-child interactional relationships. In anxiety styles, children are hesitating whether the caregiver is available and reachable. For this reason, children demonstrate adherence to the caregiver, excessive concentration to the attachment figure instead of exploring the environment, failure to cope with the absence of attachment figure, and lack of social relationships (Haugaard and Hazan, 2004). On the other hand, in the avoidance style, the child tends to be indifferent to the caregiver, to move away, and usually avoid her/him. According to these features, avoidant attachment style may not be a predictor of school refusal. However, the children having this style are also insufficient in problem solving. In this case, when they have some school related problems, they may not cope with the problems effectively, and this situation may result in school refusal. Thus, our findings suggest that the predictivity of attachment styles on school refusal should be examined from a personal perspective with the qualitative method in order to understand the meaning of the attachment and to see its effects.

Some demographical variables' relation to school refusal were also investigated. The results indicated that gender had not yield any differences on school refusal. There are inconsistent study results in the literature. In some studies (Heyne et al., 2001; King \& Bernstein, 2001), it is reported that school refusal is at equal rates in both genders; however, in another study (Nishida, Sugiyama, Aoki, \& Kuroda, 2004), higher rates are shown for men. Based on the 
Tekin, I., Erden, S., Şirin Ayva, A. B., \& Büyüköksüz, E. (2018). The predictors of school refusal: Depression, anxiety, cognitive distortion and attachment. Journal of Human Sciences, 15(3), 1519-1529. doi:10.14687/jhs.v15i3.5084

results, it can be stated that the roots of school refusal behaviours have more specific features, and cannot be completely explained through gender stereotypes.

Perceived socio-economic level was also taken into consideration as a variable. Results have presented that perceived socio-economic level has an effect on children's school refusal behaviours. When means were compared, it could be seen that the difference occurs between the lowest and the highest status. It means that children having lowest socio-economic level are more likely to experience school refusal. Perception of lower socio-economic level negatively affects person's evaluations about self, others, and world. Similarly, Egger Castello, and Angold (2003) described a group of school refusers who have experienced anxiety and depression. They also indicated that the lower socio-economic status leads to higher absenteeism rates. From the findings, it can be thought that the low socioeconomic level may lead to school refusal behaviours.

Finally, the effect of the education level of parents was examined. The findings showed that parents' educational status did not yield any differences. Kearney, Lemos and Silverman (2006) claimed that external variables often play a key role in school refusal behaviour. Parental education level as a non-psychological factor is seen as one of the variables, and it is inversely associated with child absenteeism. Similarly, Bahalı, Tahiroğlu, Avc1, and Seydaoğlu, (2011) also found out that parents of the school refusal children had lower levels of education compared with other children's parents. It was found that the first group students had higher anxiety and depression scores. However, the finding of our study suggests that instead of the parents' educational level, their attitudes and behaviours should be examined.

It can be concluded from the research findings that there are significant relationships between school refusal, attachment styles, anxiety, depression, and negative thoughts. Moreover, anxiety, depression, and negative thoughts significantly predict school refusal whereas attachment styles do not. Our findings in some aspects conform to the previous studies and the related literature, but in some aspects, they show different results. Therefore, more researches conducted through different study designs are needed in order to generalize the findings of our research.

The relationship among school refusal, attachment styles, anxiety-depression and negative thoughts is very important for psychological counsellors, especially for the ones who work in schools. School refusal may interrupt the development of positive self-perception and healthy social relations of the refusers. Besides the emotional problems, many social and academic problems such as withdrawing from friends, not being accepted by peers, academic failure etc. can also arise.

It is crucial that counsellors are aware of the factors causing the problems, and apply individual and group counselling programs to cope with them. Skills and communication trainings should be carried out in the classrooms, and all pupils are encouraged to participate in. Therefore, these interventions will positively contribute to the child, the family, the school, and the society. On the other hand, school refusal is also vital for national education system because this problem affects the educational investments and the development of the country.

In conclusion, further researches to be carried out on the predictors of school refusal (attachment, anxiety, depression and negative thoughts) may help to raise psychologically healthier generations.

\section{References}

Bagnell, A. L. (2011). Anxiety and separation disorders. Pediatric Review, 32(10), 440-445. doi:10.1542.

Bahalı, K. Tahiroğlu, A.Y., Avc1, A. \& Seydaoğlu, G. (2011). Parental psychological symptoms and family risk factors of children and adolescents who exhibit school refusal. East Asian Arch. Psychiatry, 21, 164-169.

Bahalı, K., Tahiroğlu, A. Y., \& Avc1, A. (2009). Okul reddi olan çocuk ve ergenlerin klinik özellikleri. Anatolian Journal of Psychiatry, 10, 310-317. 
Tekin, I., Erden, S., Şirin Ayva, A. B., \& Büyüköksüz, E. (2018). The predictors of school refusal: Depression, anxiety, cognitive distortion and attachment. Journal of Human Sciences, 15(3), 1519-1529. doi:10.14687/jhs.v15i3.5084

Barth, R. P. (1984). Reducing nonattendance in elementary schools. Social Work in Education. 6, 151-166. Beck, J. (1995). Cognitive therapy: Basics and beyond. New York: Guilford Press.

Beidas, R. S., Crawley, S. A., Mychailyszyn, M. P., Comer, J. S. \& Kendall, P. C. (2010). Cognitive-Behavioral Treatment of anxious youth with comorbid school refusal: Clinical presentation and treatment response. Psychological Topics, 19 (2), 255-271.

Bilgin, M. (2004). Bilişsel Üçlü Ölçeğinin Geliştirilmesi: Geçerlik ve Güvenirlik Çalışmaları. Türk Psikolojik Danışma ve Rehberlik Dergisi. 21 (3), 35-41.

Brenning, K., Soenens, B., Braet, C. \& Bosmans, G. (2011). An adaptation of the experiences in close relationships scale revised for use with children and adolescent. Journal of Social and Personal Relationships, 28, 1048-1072

Chorpita, B. F., Yim, L., Moffitt, C., Umemoto, L. A., \& Francis, S. E. (2000). Assessment of symptoms of DSM-IV anxiety and depression in children: A revised child anxiety and depression scale. Behavior Research and Therapy, 38, 835-855. doi:10.1016/S0005 7967(99)00130-8

Christogiorgos, S. \& Giannakopoulos, G. (2014). School refusal and the parent-child relationship: A psychodynamic perspective. Journal of Infant, Child, and Adolescent Psychotherapy, 13, 182-192, DOI: 10.1080/15289168.2014.937976.

Dube, S. R., \& Orpinas, P. (2009). Understanding excessive school absenteeism as school refusal behavior. Children \& Schools, 31(2), 87-95. DOI: 10.1093/cs/31.2.87

Ebesutani, C., Reise, S. P., Chorpita, B. F., Ale, C., Regan, J., Young, J., Higa-McMillan, C. \& Weisz J.R. (2012). The Revised Child Anxiety and Depression Scale-Short Version: Scale reduction via exploratory bifactor modelling of the broad anxiety factor. Psychological Assessment, 24, (4) 833-845.

Egger, H., Castello, E. J., \& Angold, A. (2003). School refusal and psychiatric disorders: A community study. Journal of the American Academy of Child and Adolescent Psychiatry, 42, 797-807.

Fraley, R. C., Waller, N. G. and Brennan, K. A. (2000). An item response theory analysis of self-report measures of adult attachment. Journal of Personality and Social Psychology, 78, 350-365.

Fremont, W. P. (2003). School refusal in children and adolescents. American Family Physician, 68(8), 15551560.

Haight, Kearney, Hendron \& Schafer (2011). Confirmatory Analyses of School Refusal Assessment Scale-Revised: Replication and Extension to a Truancy Sample. Psychopathology Behavioral Assessment, (33), 196-204.

Hanna, G. L., Fischer, D. J., \& Fluent, T. E. (2006). Separation anxiety disorder and school refusal in children and adolescents. Pediatrics in Review, 27, 56-63.

Haugaard, J. J., \& Hazan, C. (2004). Recognizing and treating uncommon behavioral andemotional disorders in children and adolescents who have been severely maltreated: Reactive attachment disorder. Child Maltreatment, 9, 154-160. DOI:10.1177/1077559504264316

Heyne, D., King, N.J., Tonge, B.J., \& Cooper, H. (2001). School refusal: Epidemiology and management. Pediatrics Drugs, 3, 719-32. doi:10.2165/00128072-200103100-00002.

Iwata, M., Hazama, G., \& Nakagome, K. (2012). Depressive state due to isolated and adrenocorticotropic hormone deficiency underlines school refusal. Psychiatry and Clinical Neurosciences. 66, 243-244.

Karasar, N. (2006). Bilimsel araştrma yöntemi. (16. bs). Ankara: Nobel Yayınları.

Kearney, C. A. (2001). School refusal behaviour in youth: A functional approach to assessment and treatment. Washington DC., American Psychological Association.

Kearney, C.A. (2003). Bridging the gap among professionals who address youths with schoolabsenteeism: Overview and suggestions for consensus. Professional Psychology: Research and Practice, 34,57-65.

Kearney, C. A. (2008a). Helping School Refusing Children and Their Parents: A Guide for School-based Professionals. Oxford University Press, New York.

Kearney, C. A. (2008b). School absenteeism and school refusal behavior in youth: A contemporary review. Clinical psychology review, 28(3), 451-471.

Kearney, C. A., \& Bates, M. (2005). Addressing school refusal behavior: Suggestions for frontline professionals. Children \& Schools, 27(4), 207-216. DOI: 10.1093/cs/27.4.207.

Kearney, C. A. \& Bensaheb, A. (2006). School Absenteeism and School Refusal Behavior: A Review and Suggestions for School-Based Health Professionals. The Journal of School Health, 76 (1), 3-8.

Kearney, C. A. \& Hugelshofer, D. S. (2000). Systemic and Clinical Strategies for Preventings School Refusal. Journal of Cognitive Psychotherapy: An International Quarterly, $14 \quad$ (1), 51-66. 
Tekin, I., Erden, S., Şirin Ayva, A. B., \& Büyüköksüz, E. (2018). The predictors of school refusal: Depression, anxiety, cognitive distortion and attachment. Journal of Human Sciences, 15(3), 1519-1529. doi:10.14687/jhs.v15i3.5084

Kearney, C. A., Lemos, A. \& Silverman, J. (2006). School Refusal Behaviour. In R. B. Mennuti, Christner, R. W.. and A. Freeman, (Eds.), Cognitive Behavioral Interventions $\quad$ in Educational Settings (pp. 161187).Newyork: Taylor \& Francis Group.

Kearney, C. A. \& Roblek, T, L. 1997. Parent training in the treatment of school refusal behavior.In Handbook of Parent Training: Parents as Co-Therapists for Children's Behavior Problems (2nded.), Briesmeister, J. M. \& Schaefer, C. D. (eds). Wiley: New York; 225-226.

Kearney, C. A. \& Silverman, W.K. (1993). Measuring the function of school refusal behavior: the school refusal assessment scale. Journal of Clinical Child Psychology, 22 (1), 85-96.

Kearney, C.A., \& Silverman, W.K. (1999). Functionally-based prescriptive andnonprescriptive treatment for children and adolescents with school refusal behavior. Behavior Therapy, 30, 673-695.

Kesebir, S., Kavzoğlu, S. Ö., \& Üstündağ, M. F. (2011). Bağlanma ve psikopatoloji. Psikiyatride Güncel Yakelasimlar, 3(2).

Kendall, P. (1991). Guiding theory for therapy with children and adolescents. In P. Kendall (Ed.), Child and Adolescent Therapy: Cognitive-behavioral procedure (pp. 3-24). New York: The Guilford Press.

Kırımer, F., Akça, E. \& Sümer, N. (2014). Orta çocuklukta anneye kaygılı ve kaçınan bağlanma: Yakın İlişkilerde Yaşantılar Envanteri-II Orta Çocukluk Dönemi Ölçeğinin Türkçeye uyarlanması. Türk Psikoloji Yazllar, 17 (33), 45-57.

King, N. J. \& Bernstein, G. A. (2001). School refusal in children and adolescents: A review of the past 10 years. J. Am. Acad. Child Adolescent Psychiatry, 40,197-205.

Last, C. \& Strauss, C. (1990). School refusal in anxiety disordered children and adolescents. Journal of the American Academy of Child and Adolescent Psychiatry, 29, 31-35.

Maric, M., Heyne, D. A., Heus, P., Widenfelt, B. M. \& Westenberg, P. M. (2012). The Role of Cognition in School Refusal: An Investigation of Automatic Thoughts and Cognitive Errors. Behavioural and Cognitive Psychotherapy, 40, 255-269.

Martin, C., Cabrol, S., Bouvard, M. P., Lepine, J. P., \& Mouren-Simeoni, M. C. (1999). Anxiety and depressive disorders in fathers and mothers of anxious school-refusing children. Journal of the American Academy of Child \& Adolescent Psychiatry, 38(7), 916-922.

Moss, E., \& St-Laurent, D. (2001). Attachment at school age and academic performance. Developmental psychology, 37(6), 863.

Nishida, A., Sugiyama, S., Aoki, S., \& Kuroda, S. (2004). Characteristics and outcomes of school refusal in Hiroshima, Japan: proposals for network therapy. Acta Medica Okayama, 58, $241-9$.

Özcan, Ö., Kılıç, B. G., \& Aysev, A. (2006). Okul korkusu yakınması olan çocukların anababalarında uhsal bozukluklar. Türk Psikiyatri Dergisi, 17(3), 173-180.

Reid, K. (2000). Tackling truancy in school: A practical manual for primary and secondary schools. London, United Kingdom: Routledge.

Seçer, İ. (2014). Okul Ret Ölçeğinin Türkçeye Uyarlanması: Güvenirlik ve geçerlik çalışması. ～EJER Congress sunulan sözlü bildiri, İstanbul.

Seçer, İ. \& Şimşek, M.K. (2015). Reviz̧e Edilmiş Cocuklar için Anksiyete ve Depresyon Ölçeği Kısa Formu. Ejer Congres, sözlü bildiri. Ankara

Selçuk, E., Günaydin, G., Sümer, N. \& Uysal A. (2005). Yetişkin bağlanma boyutları için yeni bir ölçüm: Yakın İlişkilerde Yaşantılar Envanteri-II'nin Türk örnekleminde psikometrik açıdan değerlendirilmesi. Türk Psikoloji Yąılar, 8, 1-11.

Sewell, J. (2008). School refusal. Australian Family Physician, 37 (6), 406-409.

Wimmer, M. (2008). School refusal. Principal Leadership, 8, (8). 10-15.

Wu, X., Liu, F., Cai, H., Huang, L., Li, Y., Mo, Z. \& Lin, J. (2013). Cognitive behavioural therapy combined fluoxetine treatment superior to cognitive behaviour therapy alone for school refusal. International Journal of Pharmacology, 9 (3), 197-203. 